\title{
The Choice to Go Organic: Evidence from Small US Farms
}

\author{
Xuanli Liu $^{1}$, Nalini Pattanaik ${ }^{1}$, Mack Nelson ${ }^{2}$, Mohammed Ibrahim ${ }^{1}$ \\ ${ }^{1}$ Agricultural Research Station, Fort Valley State University, Fort Valley, USA \\ ${ }^{2}$ Department of Business and Economics, Fort Valley State University, Fort Valley, USA \\ Email: *liux@fvsu.edu
}

How to cite this paper: Liu, X.L., Pattanaik, N., Nelson, M. and Ibrahim, M. (2019) The Choice to Go Organic: Evidence from Small US Farms. Agricultural Sciences, 10, 1566-1580.

https://doi.org/10.4236/as.2019.1012115

Received: October 8, 2019

Accepted: December 8, 2019

Published: December 11, 2019

Copyright (c) 2019 by author(s) and Scientific Research Publishing Inc. This work is licensed under the Creative Commons Attribution International License (CC BY 4.0).

http://creativecommons.org/licenses/by/4.0/

(c) (i) Open Access

\begin{abstract}
This research examined small farmers' operational choice in converting to organic farming in the Southern region of the United States. A logistic model fitted to survey data from responses of 456 produce growers found the key determinants of the conversion choices of farmers and offered quantitative impacts of the major influential factors retained in the fitted model. Among them, barriers to the conversion were linked to farmer's age, risk aversion, years of farming, and the lack of education as well as low yield of organic farming; nevertheless, the model also revealed the existence of stimuli reflecting on access to farmers markets, peer exemplars, and operational scale. The confluence of variables retained partially explained a slow but steady conversion to organic farming in the United States. Besides the broad implication for policy making in the agricultural sector, this study found that organic farming was closely tied to small farms and organic farming could be a back road to the future of small US farms.
\end{abstract}

\section{Keywords}

Organics, Barriers, Produce, Organic Farming, Small Farms

\section{Introduction}

Recent years witnessed substantial growth in sales of US organic food [1] [2] [3]. The annual growth rate of organic food sales between 1990 and 2017 reached a double digit ranged from $12 \%$ to $21 \%$, far outpaced the growth of products conventionally produced [2]. In 2106, the total sales of organic products had grown to $\$ 47$ billion [4].

The fast-expanding US organic market was partially attributed to the strong demand due to an increasing number of consumers' preference for buying and 
consuming organic foods. The niche market had embraced as high as $69 \%$ of US consumers [5] and they were willing to pay the premium prices for organic products [6] [7] [8] [9] [10]. The driving forces behind include growing concerns about health, valuing food safety, environmental shepherd, and animal welfare [11] [12]. The conversion to organic foods was particularly significant in consumers' favor for organic produce [7] [10] [13].

While the solid demand for organic products unfolded in both domestic and international food markets, the supply side revealed a relatively stagnant growth within the United States. Overall, organic production has not kept pace with the growth in demand, organic farms are struggling, and organic handlers are challenged for procuring enough [7] [14]. At the very upstream of supply chain, organic farming remains a tiny share, accounting for about $0.55 \%$ of the total US farm land [15].

The shortage of supply along the organic chain has been much in evidence for years in the United States. When it comes to the major barriers, studies point to low yields, higher costs, unstable product quality, the cost of certification, price premiums, imports, limited organic inputs, and the lopsided competitions [6] [16] [17] [18]. Some others render explanations with focuses on psychological and sociological costs [19], on uncertain legislative environment [1], on security of marketing channels [20] [21], on input constraints [22], and the perceptions of farmers [23]. While the varieties of investigations did cover a broad area, the results are mixed. The lack of consensus regarding the influential factors and their impact on organic conversion calls for more quantitative analyses based on good survey data, and some studies based on econometric models step forward to quantitatively address the choice of farmers on the conversion to organic production and reached conclusions that related organic farming to the age and gender of operators, farming acreages, levels of education, and urban-raised farmers, which did not fully resonate with some early analyses, but provided a more informative vision [21] [24] [25] [26]. Despite the progress, a closer look at the limited studies finds a problem of small sample size, which is linked to problematic estimates of impacts in spite of their significance in statistics. This is a well-recognized issue to many, but has a tendency to repeat itself due to the predicament in organizing interviews and collecting data. Consequently, conflicts remain even in this category of studies. The situation merits more studies with the well-designed survey instruments and relatively large samples to ensure more accurate and consistent estimates of the impacts of influential factors in the small-farmers' decision-making on the conversion to organic production.

This study has its focus on the choice of small farmers in the conversion to organic production and is aimed to identify the factors of the influence and validate their impacts on farmers' decision on the conversion to organic production. Based on a large survey data in the Southern region of the United States, the authors examined farmer's attitude, perception, farms characteristics, features of the local community, social demographic factors, and so forth. The re- 
sults supplemented some conclusions of early studies and offered a deeper understanding of choices of farmers in the conversion to organic farming in the United States. A broad survey and econometric modeling featured this study make the analysis ready to the empirical application and bring about the important implications for understanding the complex organic conversion process and for making workable and effective polices to support the small farms in the United States.

\section{Data}

The data used in this study came from a broad interview with small farmers in Southern region of USA in 2014. The information collected covered organic practices adopted, societal and demographics of operators; characteristics of farms; farmers' beliefs, attitudes, and perceptions related to organic farming practices, and so forth. A large sample of farmers from a population of total 4818 farms in Georgia were randomly selected and interviewed. The instruments used in the interview were designed by faculty members of Fort Valley State University and the field work of the survey was administered by the Burruss Institute of Kennesaw State University. Farmers who respond to the screening question, "Do you produce fruits and vegetables?" with a "yes" were retained in the sample. The qualified interviewees were contacted multiple times to obtain an effective sample size. About 2404 farmers were contacted, with 456 farmers going through the survey, which gave a return rate of $18.9 \%$. The instruments encompass a broad spectrum of questions pertinent to production practices, social demographics, individual attitude, beliefs, perceptions, as well as the characteristics of farms. The organic production in the survey may take the form of the USDA certified, certification exempt, or transitioning farms. The interview were conducted by trained personnel following the well-established procedures, which insures the veracity of data collected. However, it is also in evidence that some self-selection biases occurred due to the fact that the higher level of education were associated with organic producers and they were inclined to finish the survey retained in the sample, which make the organic operations in the sample high than the overall percentage in Georgia farms in 2012 Census of Agriculture. The defect may constrain the effort to reach a general extrapolation beyond the survey data. In Table 1, the variables covered in the survey and the corresponding preliminary statistics were reported to provide a profile of small farmers in the Southern region of states.

\section{Research Methods}

We approached farmers' choice of organic farming and potential factors of influence with the help of the logit regression model. After comparative study on the logit, the probit, and the linear probability models, being alike in ways in analyzing categorical data [27] [28] [29], we first exclude the linear probability model for its bias and inefficiency [28] [30]. The logit and probit models are 
Table 1. Selected variables and frequency.

\begin{tabular}{|c|c|c|c|c|c|}
\hline Variable & Description & Percent $(\%)^{*}$ & Variable & Description & Percent $(\%)^{*}$ \\
\hline \multirow{4}{*}{ Farm Type } & Pure farming type & & \multirow{4}{*}{$\begin{array}{l}\text { Farming } \\
\text { Income }\end{array}$} & Gross farm sales & \\
\hline & $0=$ Conventional & 39.85 & & $0 \leq \$ 50,000$ & 62.41 \\
\hline & $1=$ Mixed Farm & 29.18 & & $1=50,000-100,000$ & 18.05 \\
\hline & $2=$ Pure Organic & 29.95 & & $2 \geq \$ 100,000$ & 19.55 \\
\hline \multirow{6}{*}{ Age of Operator } & Age of farmer & & \multirow{3}{*}{$\begin{array}{c}\text { Marketing at } \\
\text { Farmers } \\
\text { Market }\end{array}$} & Use farmers market & \\
\hline & $0=30 \&$ Younger & 6.06 & & $0=$ Not & 56.19 \\
\hline & $1=31-40$ & 8.59 & & $1=$ Yes & 43.07 \\
\hline & $2=41-50$ & 17.68 & \multirow{4}{*}{$\begin{array}{c}\text { Perception of } \\
\text { Consumer as Barrier }\end{array}$} & Find reliable buyers & \\
\hline & $3=51-60$ & 29.04 & & $0=$ Not a barrier & 54.02 \\
\hline & $4=61-70$ & 23.48 & & $1=$ Minor barrier & 29.31 \\
\hline \multirow{5}{*}{ Years of Farming } & $5=$ Over 70 & 14.90 & & $2=$ Major barrier & 16.67 \\
\hline & Yrs. farming exp. & & \multirow{3}{*}{$\begin{array}{l}\text { Need Exemplar } \\
\text { to Follow }\end{array}$} & Need successful exemplar & \\
\hline & $0=0-5$ years & 10.82 & & $0=$ Disagree & 44.68 \\
\hline & $1=6-11$ years & 10.82 & & $1=$ Agree & 55.32 \\
\hline & $2=12 \&$ more years & 78.36 & \multirow{4}{*}{$\begin{array}{l}\text { Organic Yield } \\
\text { as Barrier }\end{array}$} & Organic has lower yield & \\
\hline \multirow{3}{*}{ Off-farm Work } & Work off-farm or not & & & $0=$ Disagree & 35.19 \\
\hline & $1=\mathrm{No}$ & 59.90 & & $1=$ Agree & 64.81 \\
\hline & $2=\mathrm{Yes}$ & 39.61 & & & \\
\hline \multirow{3}{*}{$\begin{array}{l}\text { Level of } \\
\text { Education }\end{array}$} & Years of education & & & & \\
\hline & $0=$ H.S. \& less & 23.87 & & & \\
\hline & $1=$ Greater than H.S & 74.13 & & & \\
\hline
\end{tabular}

*The percentage sum of each variable may not equal 100 due to the responses of unknown or inapplicable information.

arguably equivalent, only many investigators prefer the former for easy interpretation of parameters. For the sake of comparability, we used the logit model hereof. Since rich documents related to the logit model are readily available in the literature [31] [32], the authors just present a model brief in the context of this investigation, rather than a thoroughgoing model discussion in the coming section.

Following [31], we assumed a random variable $Y_{i}$, taking one of three discrete values indexed as $1,2,3$, representing three operational choices: pure conventional, mixed, and pure organic operation respectively. Let

$$
P_{i j}=\operatorname{Pr}\left(Y_{i j}\right)
$$

Denotes the probability that the $I^{\text {th }}$ response choice falls in the $f^{\text {th }}$ category. So, $P_{i 1}$ represents the probability that the farmer $i$ choose to do conventional farming. It was assumed that log-odds of choice $j$ of respondent $i$ with reference to the choice 1 follows a linear relation as described in Equation (2). 


$$
\eta_{i j}=\log \frac{p_{i j}}{p_{i 1}}=\beta_{0}+X^{\prime} \beta_{j} \text { for } j=2,3
$$

where $\beta_{0}$ is a constant, and $\beta_{j}$ is a vector of regression coefficient for $j=2$ and 3 .

The model above is analogous to a simple logistic regression model, except that the probability distribution of the response is multinomial instead of binomial and two equations are estimated instead of one. The equations contrasted each of categories 2 and 3 with the choice 1, whereas the simple logistic regression is just a contrast between success and failure. In the support of SAS software, two models were fitted with the likelihood maximization method. The coefficient vector $\beta_{\mathrm{j}}$ is associated with a set of explanatory variables and measures the change in log odds for a one-unit increase in $X_{i}$. The odds ratio derived is the change in ratio of the odds for a one-unit change in $X_{i}$ [33].

In order to have an easier and intuitive interpretation of the impact from each factor, the probability of each choice was estimated. Then, the marginal impact of each factor on probability of a choice were able to be derived from the three equations below:

$$
\begin{aligned}
& \operatorname{Pr}(Y=1)=\frac{1}{\mathrm{e}^{X \beta^{(1)}}+\mathrm{e}^{X \beta^{(2)}}+\mathrm{e}^{X \beta^{(3)}}} \\
& \operatorname{Pr}(Y=2)=\frac{\mathrm{e}^{X \beta^{(2)}}}{\mathrm{e}^{X \beta^{(1)}}+\mathrm{e}^{X \beta^{(2)}}+\mathrm{e}^{X \beta^{(3)}}} \\
& \operatorname{Pr}(Y=3)=\frac{\mathrm{e}^{X \beta^{(3)}}}{\mathrm{e}^{X \beta^{(1)}}+\mathrm{e}^{X \beta^{(2)}}+\mathrm{e}^{X \beta^{(3)}}}
\end{aligned}
$$

As usual, the most challenging part of modelling is associated with model selection among many alternatives. In this study, we adopted the approach of Purposeful Selection of Variables [34], which usually retains important confounding variables and result potentially in a slightly richer model. We began our model fitting by a univariate analysis of all variable relevant. Any variable with a significant univariate test at 0.25 level was selected as a candidate for the multivariate analysis. In an iterative process, covariates are removed from the model if they are non-significant and not a confounder. Significance is evaluated at the 0.1 level and confounding as a change in any remaining parameter estimate greater than $15 \%$ as compared to the full model. A change in a parameter estimate above the $15 \%$ indicates that the excluded variable was important in the sense of providing a needed adjustment for one or more of the variables remaining in the model. At the end of this iterative process of deleting, refitting, and verifying, the model contains significant covariates and confounders. Then, we took into account of any variable not selected for the original multivariate model and added them back one at a time, with all significant covariates and confounders retained earlier. In such a way, other variables which, by themselves, were not significantly related to the outcome but became an important contributor in the presence of other variables will be included in the final model. 
All variables that are significant at the 0.1 level were put in the model, and the model was iteratively reduced as before but only for the variables that were additionally added. Following the steps above, we obtained a final version of model as organized and presented in Table 2 and Table 3 . The former is in terms of log odds and the latter in terms of probability.

Table 2. The maximum likelihood estimates of the farmers' choice logit model.

\begin{tabular}{|c|c|c|c|c|c|}
\hline Parameter & q1 & Estimate & Standard Error & Wald Chi Square & $\operatorname{Pr}>$ ChiSq \\
\hline Intercept & Mixed & 2.32 & 1.08 & 4.62 & 0.03 \\
\hline Intercept & Pure & 4.44 & 1.19 & 13.95 & 0.00 \\
\hline Farmers market & Mixed & 0.59 & 0.37 & 2.55 & 0.11 \\
\hline Farmers market & Pure & 2.23 & 0.44 & 25.29 & $<0.0001$ \\
\hline Reliable buyer & Mixed & 0.38 & 0.35 & 1.14 & 0.29 \\
\hline Reliable buyer & Pure & -0.60 & 0.43 & 1.98 & 0.16 \\
\hline Need exemplar & Mixed & -0.72 & 0.37 & 3.79 & 0.05 \\
\hline Need exemplar & Pure & -2.01 & 0.44 & 20.95 & $<0.0001$ \\
\hline Impact of low organic yield & Mixed & -0.11 & 0.40 & 0.08 & 0.78 \\
\hline Impact of low organic yield & Pure & -0.95 & 0.43 & 4.81 & 0.03 \\
\hline Liability related to organic & Mixed & 0.18 & 0.36 & 0.26 & 0.61 \\
\hline Liability related to organic & Pure & -0.71 & 0.42 & 2.77 & 0.10 \\
\hline Operator age ( $31-60$ vs 30 or less) & Mixed & -1.46 & 0.93 & 2.46 & 0.12 \\
\hline Operator age( $31-60$ vs 30 or less) & Pure & -2.45 & 1.01 & 5.92 & 0.02 \\
\hline Operator age (61 or above vs 30 or less) & Mixed & -1.35 & 0.99 & 1.87 & 0.17 \\
\hline Operator age (61 or above vs 30 or less) & Pure & -2.73 & 1.10 & 6.13 & 0.01 \\
\hline Farming years & Mixed & -0.01 & 0.01 & 1.80 & 0.18 \\
\hline Farming years & Pure & -0.04 & 0.01 & 10.34 & 0.00 \\
\hline Level of education & Mixed & -0.26 & 0.43 & 0.37 & 0.54 \\
\hline Level of education & Pure & 0.86 & 0.57 & 2.28 & 0.13 \\
\hline Off-farm work & Mixed & -0.19 & 0.38 & 0.25 & 0.62 \\
\hline Off-farm work & Pure & -0.43 & 0.43 & 0.97 & 0.32 \\
\hline Medium size farm vs small & Mixed & -0.44 & 0.45 & 0.96 & 0.33 \\
\hline Medium size farm vs small & Pure & -0.33 & 0.52 & 0.39 & 0.53 \\
\hline Large size farm vs small & mixed & -1.37 & 0.46 & 8.95 & 0.00 \\
\hline Large size farm vs small & Pure & -2.48 & 0.69 & 12.78 & 0.00 \\
\hline
\end{tabular}

${ }^{*}$ Note: Triple, double, and single asterisks indicate significance at the $1 \%, 5 \%$, and $10 \%$ level, respectively. Mixed $=$ organic and Conventional, Pure $=$ all organic, and Con $=$ Conventional, Likelihood Ratio $(\mathrm{Pr}<\mathrm{ChiSq})<0.0001$. 
Table 3. Probability and marginal impact of influential factors.

\begin{tabular}{|c|c|c|c|c|c|c|c|}
\hline & & $\mathrm{dy} / \mathrm{dx}$ & Std. Err. & $\mathbf{z}$ & $P>|z|$ & [95\% conf. & Interval] \\
\hline \multirow[t]{4}{*}{ Farmers Market } & _predict & & & & & & \\
\hline & 1 & -0.1962 & 0.0565 & -3.4700 & 0.0010 & -0.3070 & -0.0854 \\
\hline & 2 & -0.0717 & 0.0605 & -1.1900 & 0.2360 & -0.1903 & 0.0468 \\
\hline & 3 & 0.2679 & 0.0517 & 5.1800 & 0.0000 & 0.1665 & 0.3693 \\
\hline \multirow[t]{4}{*}{ Reliable buyers } & _predict & & & & & & \\
\hline & 1 & -0.0088 & 0.0509 & -0.1700 & 0.8620 & -0.1086 & 0.0910 \\
\hline & 2 & 0.1143 & 0.0552 & 2.0700 & 0.0380 & 0.0062 & 0.2224 \\
\hline & 3 & -0.1055 & 0.0467 & -2.2600 & 0.0240 & -0.1969 & -0.0140 \\
\hline \multirow[t]{4}{*}{ Rule of exemplar } & _predict & & & & & & \\
\hline & 1 & 0.1879 & 0.0531 & 3.5400 & 0.0000 & 0.0839 & 0.2919 \\
\hline & 2 & 0.0278 & 0.0572 & 0.4900 & 0.6270 & -0.0844 & 0.1400 \\
\hline & 3 & -0.2157 & 0.0490 & -4.4000 & 0.0000 & -0.3116 & -0.1197 \\
\hline \multirow[t]{4}{*}{ Low yield of organic } & _predict & & & & & & \\
\hline & 1 & 0.0638 & 0.0558 & 1.1400 & 0.2520 & -0.0455 & 0.1731 \\
\hline & 2 & 0.0553 & 0.0595 & 0.9300 & 0.3520 & -0.0613 & 0.1720 \\
\hline & 3 & -0.1192 & 0.0505 & -2.3600 & 0.0180 & -0.2181 & -0.0202 \\
\hline \multirow[t]{4}{*}{$\begin{array}{l}\text { High liability } \\
\text { of organic }\end{array}$} & _predict & & & & & & \\
\hline & 1 & 0.0182 & 0.0517 & 0.3500 & 0.7250 & -0.0831 & 0.1195 \\
\hline & 2 & 0.0875 & 0.0558 & 1.5700 & 0.1170 & -0.0219 & 0.1969 \\
\hline & 3 & -0.1057 & 0.0476 & -2.2200 & 0.0260 & -0.1990 & -0.0125 \\
\hline \multirow{4}{*}{$\begin{array}{l}\text { Age of operator } \\
\text { (3160 vs } 30 \text { or less) }\end{array}$} & _predict & & & & & & \\
\hline & 1 & 0.2285 & 0.0822 & 2.7800 & 0.0050 & 0.0674 & 0.3895 \\
\hline & 2 & -0.0293 & 0.1103 & -0.2700 & 0.7900 & -0.2454 & 0.1868 \\
\hline & 3 & -0.1992 & 0.0973 & -2.0500 & 0.0410 & -0.3899 & -0.0085 \\
\hline \multirow[t]{5}{*}{$\begin{array}{l}\text { Age of operator } \\
\text { (61 or above } \\
\text { vs } 30 \text { or less) }\end{array}$} & _predict & & & & & & \\
\hline & 1 & 0.2285 & 0.0822 & 2.7800 & 0.0050 & 0.0674 & 0.3895 \\
\hline & 2 & -0.0293 & 0.1103 & -0.2700 & 0.7900 & -0.2454 & 0.1868 \\
\hline & 3 & -0.1992 & 0.0973 & -2.0500 & 0.0410 & -0.3899 & -0.0085 \\
\hline & & $\mathrm{dy} / \mathrm{dx}$ & Std. Err. & $\mathrm{z}$ & $P>|z|$ & [95\% conf. & Interval] \\
\hline \multirow[t]{4}{*}{ Years of farming } & _predict & & & & & & \\
\hline & 1 & 0.0036 & 0.0014 & 2.5000 & 0.0120 & 0.0008 & 0.0063 \\
\hline & 2 & 0.0006 & 0.0016 & 0.4000 & 0.6920 & -0.0025 & 0.0037 \\
\hline & 3 & -0.0042 & 0.0013 & -3.1200 & 0.0020 & -0.0068 & -0.0016 \\
\hline
\end{tabular}




\section{Continued}

\begin{tabular}{|c|c|c|c|c|c|c|c|}
\hline \multirow[t]{4}{*}{ Education level } & _predict & & & & & & \\
\hline & 1 & -0.0094 & 0.0673 & -0.1400 & 0.8880 & -0.1413 & 0.1224 \\
\hline & 2 & -0.1159 & 0.0747 & -1.5500 & 0.1210 & -0.2624 & 0.0306 \\
\hline & 3 & 0.1254 & 0.0574 & 2.1800 & 0.0290 & 0.0128 & 0.2379 \\
\hline \multirow[t]{4}{*}{ Off- farm work } & _predict & & & & & & \\
\hline & 1 & 0.0413 & 0.0539 & 0.7700 & 0.4430 & -0.0643 & 0.1470 \\
\hline & 2 & -0.0017 & 0.0573 & -0.0300 & 0.9770 & -0.1140 & 0.1107 \\
\hline & 3 & -0.0397 & 0.0460 & -0.8600 & 0.3880 & -0.1298 & 0.0505 \\
\hline \multirow[t]{4}{*}{$\begin{array}{l}\text { Medium size } \\
\text { farm vs small }\end{array}$} & _predict & & & & & & \\
\hline & 1 & 0.0650 & 0.0675 & 0.9600 & 0.3350 & -0.0673 & 0.1972 \\
\hline & 2 & -0.0554 & 0.0711 & -0.7800 & 0.4350 & -0.1947 & 0.0838 \\
\hline & 3 & -0.0096 & 0.0608 & -0.1600 & 0.8750 & -0.1288 & 0.1097 \\
\hline \multirow[t]{4}{*}{$\begin{array}{c}\text { Large size } \\
\text { farm vs small }\end{array}$} & _predict & & & & & & \\
\hline & 1 & 0.3069 & 0.0778 & 3.9500 & 0.0000 & 0.1545 & 0.4593 \\
\hline & 2 & -0.0999 & 0.0742 & -1.3500 & 0.1780 & -0.2453 & 0.0456 \\
\hline & 3 & -0.2071 & 0.0651 & -3.1800 & 0.0010 & -0.3346 & -0.0795 \\
\hline
\end{tabular}

Note: $\mathrm{dy} / \mathrm{dx}$ for factor levels is the discrete change from the base level. _predict 1 is the probability of conventional farming; _predict 2 is the probability of the mix of conventional and organic farming; _predict 3 is the probability of pure organic farming.

\section{Results and Discussions}

The fitted models reported in Table 2 and Table 3 are significant at the $1 \%$ level in terms of AIC, BIC, and Score statistics. Ten variables were retained at the $10 \%$ significant level, reflecting the responses to the following survey questions: "Do you use farmers market as a marketing outlet?"; "Do you find reliable buyers for your organic products?"; "Do you start organic farming by following some successful peers?"; "Do you believe organic farming is more prone to lower yield than that of conventional farming?"; "Do you believe that more liability incurred in organic farming?"; "Do you have an off-farm job?"; "What is the size category of your farm?"; in addition, questions related to age, years of farming experience, and years of education of the major operator were identified as independent variables of influence in the decision making process of farmers. The following discussion will be on important impact of each identified factor in the finalized model.

\subsection{Marketing Channels and Their Impacts}

The marketing channel is identified as a key factor on farmers' conversion decision. We were attentive to the long list of marketing channels, including farmers market, roadside stands, directly to consumers, wholesale markets, processors, 
restaurants, food stores, and schools. The access to farmers market was retained in the model as a significant factor. Producers who sell on farmers market had a $26 \%$ increment of probability in converting to organic farming in comparison with those with no access. Similarly, the accessibility reduced the likelihood of farmers remaining in conventional farming by $19.6 \%$. The impact is the largest among all influential variables, which implies the vital role of the farmers market for organic products. Farmers market could relate organic products to other value-added attributes such as freshness and locally produced, which enable an easy claim on premium price. In addition, farmers market tends to tolerate the unstable and inconsistent supply in both quantity and quality of organic products. The absences of other market channels in the model may not necessarily mean they are less importance, rather it likely reflected a reality that they were perceived by organic farmers as inaccessible or less accessible at the time of our survey.

\subsection{Reliable Buyers}

Finding reliable buyers was identified as a major barrier from a long list of potential ones including price premium, distance to organic markets, handling costs, and competition with non-organic products, and access to capital through lenders. Farmers with the concern was $10 \%$ less likely to convert to organic farming. The result seemed contradict the claim on a great demand for organic products. The solution to the puzzle is that existence of a great demand for organic products showed an unbalanced spatial structure and could not be extrapolated into areas not adjacent to metropolis. Confined to limited access to chain retailers, small farmers turned to the "thin" farmers markets for their products, in which finding reliable buyers turns out to be difficult and full of uncertainty.

\subsection{Lower Yield of Organic Farming}

Farmers held a perception of lower yield of organic farming is $11.92 \%$ less likely to convert to organic farming. The low yield of organic farming is not just perception, but a fact in many areas, due to the lack of high-quality seed, organic fertilizer, and effective pests and weeds sprays. The perception of low organic yield is across all farmer types [14] [35]. The perception of lower yield could easily explain farmers' behavior of withholding converting to organic farming.

\subsection{Uncertainty and Risk Factors}

A risk factor weighed in on farmers' decision on converting to organic farming, reflecting in whether farmers intend to covert to organic farming until they witness a peer's success. Those with a "Yes" composed a group of risk aversion and they were $21.57 \%$ less likely to convert to organic farming. The result was in align with previous studies in that farmers' adoption of new practices are most influenced by information from other farmers [28] [36] [37]. Currently, there 
are a small cohort of organic farming exemplar for others to imitate. Given most farmers are risk aversion, a small cohort of exemplars were the barrier for organic conversion.

\subsection{Farming Experience}

Using farmers group of 0 - 5 years' farming experience as a reference group, farmers of 6 - 11 years' experience have a chance of conversion 19.9\% lower, and farmers of 12 years or more, the drop reached $24.2 \%$. The estimates showed farmers were more likely to stick to conventional farming the longer they stayed in the business, partially due to a steep learning curve [32] [35]. The longer farming experience made them less likely to learn and shift toward a new approach of organic farming.

\subsection{The Perception of High Liability Entailed in Organic Farming}

There isn't much evidence to verify the veracity of the claim of high liability, but the perception came up with a distinct adverse impact. Farmers concerned about the higher liability in organic farming is $10.57 \%$ less likely to convert to organic farming. The conception likely came from the yield uncertainty due to damage from pests and/or weeds [38] [39], which easily results in default on loan and other financial responsibility that must be cushioned with more debts. Consequently, the perception of high liability discouraged farmers to steer their production to organic farming.

\subsection{The Production Scale of Farms}

The size of a farm matters and negatively impacts the conversion. As the production scale increases, the chance of conversion become smaller. In this sample, the chance of conversion for large farms is $20.71 \%$ lower than their smaller counterparts. some previous studies that organic production poses great managerial challenge due to the intensive labor demand in dealing with diseases, pests, applying fertilizer, and handling marketing [35], and constraints on substitution of capital for labor. As a result, production scale was deemed as an uncontentious barrier to the organic conversion.

\subsection{The Age of Farmers}

In the conversion to organic, the age of producers is another barrier. Table 3 shows that the probability of the conversion dropped substantially as producers become older. With the base group of 30 or young, the age group $31-60$ has a probability of $20 \%$ lower in adopting organic farming, and the group 61 or older has a drop of $24 \%$. It makes sense that the shorter planning horizons for older farmers offered less time to recapture investment costs and capture the long-term benefits. In addition, it was claimed that as one ages, the avoidance of risk becomes more important than expected future higher returns [40]. The conversion to organic farming also demands the time and efforts to assimilate 
organic knowledge and methods, and likely expose farmers to lower yields and non-premium price in the transition period [14] [35] [41] [42], and these surely weigh in on farmers decision on organic farming.

\subsection{Education}

Education wedged its influence in organic farming in a complex way. The chance of conversion is $13 \%$ higher for farmers who had education of technical school or higher than farmers with just high-school diploma or lower. This conformed a previous claim that farmers with some college education had higher odds of adopting organic farming [41] [42]. However, the impact of education was not observed in conventional farmers and those with mixed enterprises. The lack of observations on mixed enterprise group may be the root of the result.

\subsection{Off-Farm Job}

While some results of this study bear resemblances to previous studies, there are some noteworthy differences identified. The impact of off-farm job is one of them. Our model was not in supportive of the claim that there exists an inverse relationship between working off-farm and the adoption of organic farming because off-farm job reduce the availability of labor and hence impedes organic farming practices [23] [42] [43] [44]. On the contrary, the impact of off-farm jobs in our model lead to an increased likelihood of organic conversion, which may reflect the influence of the enhanced risk tolerance due to extra income from off-farm jobs. The absence of off-farm job variable led to substantial changes in parameters of other variables in the model, so it, though less significant in statistics, was retained in the model. The further clarification hinges on the future studies with more observations and elaborated instruments related off-farm job.

\section{Summary and Conclusions}

Analysis of the large survey in the Southern states came up with a few contributing factors in farmers' choice of conversion to organic production. The pool of factors comprise barriers and stimuli, each of them have been discussed in detail in the previous section. In view of potential impacts and the efficient way of improve the adoption of organic farming, the four factors of risk aversion, the age of operators, and the size of farms, and marketing channels deserve further elaboration.

Organic farming is still at its early stage, there exist tremendous uncertainty in both production and marketing process. For most risk version farmers, an acceptable way to follow was doing by the top dog. Nevertheless the exemplars available at this stage are quite limited. A way to increase farmers' expose to and know those successful frontrunners is to organize more workshops and training. Land grant universities and USDA agencies such as FSA and RMA could play a more active role in helping farmers overcome the risk barrier. 
The age of operators and its adverse impact certainly deserve multiple looks. From 2012 census data, about $62 \%$ of farmers were 55 or older, which was 17 years older than the age of average American workers. Old operators was significant less likely to go organic. While it isn't realistic to expect a change of age structure shortly, it makes sense to support young farmers in land requisition and in tax relief. Currently, the old operators' ownership of expensive land and the existing subsidy programs give the elder an edge to stay in farming, which forms a hindrance of the conversion to organic farming. An urgent need is to have some stimulus mechanisms to expedite the influx of the young into farming business. The change of land tenures and government subsidy programs is needed to support the business of the young beginning farmers

The third noticeable factor is the size of farm. The last century witnessed the significant land consolidation in the US agriculture. "Be large, or be out" is almost a common knowledge to all farmers. The high percentage of capital and land was under control of large farms makes the conversion to organic farming a predicament process. Increasing the organic production may hinge on the slowdown of the farmland consolidation, which may need government to steer some subside programs partially away from just a few large staple crops.

In the end, another factor, which should not be ignored, is the demand paradox along the organic food supply chain. While substantial evidence pointed to a great aggregate organic market, organic farmers did that way. Having reliable buyers is still a great concern for many small farmers. It demonstrated that access to farmers markets is vital, but not enough. Going through alternative marketing channels, such as the big box chain and food hubs is an inevitable step to ensure a stable gain in the conversion to organic farming. More studies on the way of channeling organic products to the big markets are merited in order to help producers go organic and make a living.

\section{Conflicts of Interest}

The authors declare no conflicts of interest regarding the publication of this paper.

\section{References}

[1] Kuminoff, N.V. and Wossink, A. (2010) Why Isn't More US Farmland Organic? Journal of Agricultural Economics, 61, 240-258. https://doi.org/10.1111/j.1477-9552.2009.00235.x

[2] Organic Trade Association (2011) Industry Statistics and Projected Growth. http://www.ota.com/organic/mt.business.html?printable=1

[3] Organic Trade Association (2013) Organic Trade Association's 2012 Industry Survey. Boulder.

[4] Organic Trade Association (2017) Robust Organic Sector Stays on Upward Climb, Posts New Records in U.S. Sales. https://www.ota.com/news/press-releases/19681

[5] Hartman Group (2006) Consumer Attitudes and Behavior Five Years and Later into 
the Future. Bellevue.

[6] Batte, M.T., Buren, F.N.V., Hu, W., Woods, T. and Ernst, S. (2010) Do Local Production, Organic Certification, Nutritional Claims, and Product Branding Pay in Consumer Food Choices? Agricultural and Applied Economics Association Annual Meeting, 25-27 July 2010.

[7] Green, C. (2013) Growth Patterns in the U.S. Organics Industry. https://www.ers.usda.gov/amber-waves/2013/october/growth-patterns-in-the-us-or ganic-industry/

[8] Smith, T.A., Huang, C.L. and Lin, B. (2009) Does Price or Income Affect Organic Choice? Analysis of U.S. Fresh Produce Users. Journal of Agricultural and Applied Economics, 41, 731-744. https://doi.org/10.1017/S1074070800003187

[9] Volpe, R.J. (2006) Exploring the Potential Effects of Organic Production on Contracting in American Agribusiness. American Agricultural Economics Association Annual Meeting, Long Beach.

[10] Klonsky, K. and Greene, C. (2005) Widespread Adoption of Organic Agriculture in the US: Are Market-Driven Policies Enough? American Agricultural Economics Association Annual Meeting, Providence.

[11] Greene, C., Dimitri, C., Lin, B.H., McBride, D.W., Oberholtzer, L. and Smith, T. (2009) Emerging Issues in the U.S. Organic Industry.

[12] Chan, S., Caldwell, B. and Rickard, B. (2010) An Economic Examination of Alternative Organic Cropping Systems in New York State. Cornell University, College of Agriculture and Life Sciences, Ithaca, New York. EB 2010-14.

[13] USDA (2009) Emerging Issues in the U.S. Organic Industry. https://www.ers.usda.gov/publications/pub-details/?pubid=44416

[14] Dimitri, C. and Oberholtzer, L. (2010) Expanding Demand for Organic Foods Brings Changes in Marketing.

https://www.ers.usda.gov/amber-waves/2010/march/expanding-demand-for-organi c-foods-brings-changes-in-marketing/

[15] USDA-ERS (2013) Organic Production. https://www.ers.usda.gov/data-products/organic-production/

[16] Oliver, H. (2006) Organic Dairy Demand Exceeds Supply. Natural Food Merchandise, 27, 1-14.

[17] Yeager, K. (2006) Some Opinions on Farmers Options and Obstacles to Adopting Organic Agriculture. Crop Management. https://dl.sciencesocieties.org/publications/cm/pdfs/5/1/CM-2006-0921-05-PS

[18] Wolf, T. (2006) Assessing Producers Options and Obstacles for Organic Agriculture. Crop Management.

[19] Gardebroek, C. (2006) Comparing Risk Attitudes of Organic and Non-Organic Farmers with a Bayesian Random Coefficient Model. European Review of Agricultural Economics, 33, 485-510. https://doi.org/10.1093/erae/jbl029

[20] Khaledi, M., Weseen, S., Sawyer, E., Ferguson, S. and Gray, R. (2010) Factors Influencing Partial and Complete Adoption of Organic Farming Practices in Saskatchewan. https://doi.org/10.1111/j.1744-7976.2009.01172.x

[21] Lohr, L. and Salomonsson, L. (2000) Conversion Subsidies for Organic Production: Results from Sweden and Lessons for the United States. Agricultural Economics, 22, 133-146. https://doi.org/10.1111/j.1574-0862.2000.tb00013.x

[22] Mayen, C.D., Balagtas, J.V. and Alexander, C.E. (2010) Technology Adoption and 
Technical Efficiency: Organic and Conventional Dairy Farms in the United States. American Journal of Agricultural Economics, 92, 181-195. https://doi.org/10.1093/ajae/aap018

[23] Johnson, S. (2010) Assessing Farmer Interests in Transition to Organic Production and Barriers to Expansion of Organic Production in New York State. New York State Department of Agriculture and Markets, Albany.

[24] Anderson, J., Jolly, D. and Green, R. (2005) Determinants of Farmer Adoption of Organic Production Methods in the Fresh-Market Produce Sector in California: A Logistic Regression Analysis. Annual Meeting of Western Agricultural Economics Association Annual Meeting.

[25] Cranfield, J., Henson, S. and Holliday, J. (2010) The Motives, Benefits, and Problems of Conversion to Organic Production. Agriculture and Human Values, 27, 291-306. https://doi.org/10.1007/s10460-009-9222-9

[26] Rigby, D., Young, T. and Burton, M. (2001) The Development of and Prospects for Organic Farming in the UK. Food Policy, 26, 599-613. https://doi.org/10.1016/S0306-9192(01)00023-9

[27] Capps, O. and Kramer, R.A. (1985) Analysis of Food Stamp Participation Using Qualitative Choice Models. American Journal of Agricultural Economics, 67, 49-59. https://doi.org/10.2307/1240823

[28] Jones, E., Batte, M.T. and Schnitkey, G.D. (1990) A Socioeconomic Analysis of Marketing Information Usage among Ohio Fruit Producers. Southern Journal of Agricultural Economics, 22, 99-107. https://doi.org/10.1017/S1074070800001851

[29] Pindych, R.S. and Rubinfeld, D.L. (1981) Econometric Models and Economic Forecasts. 2nd Edition, McGraw-Hill, New York.

[30] Ramanathan, R. (1995) Introductory Econometrics with Applications. 3rd Edition, The Dryden Press, Fort Worth.

[31] Green, W.H. (2007) Econometric Analysis. 6th Edition, Prentice-Hall, Upper Saddle River.

[32] Peterson, H.H., Barkley, A., Chacon-Casconte, A. and Kastens, T.L. (2012) The Motivation for Organic Grain Farming in the United States: Profits, Lifestyle, or the Environment? Journal of Agricultural and Applied Economics, 44, 137-155. https://doi.org/10.1017/S1074070800000237

[33] SAS Institute Inc. (1995) Logistic Regression: Examples Using the SAS System. Version 6, Cary.

[34] Hosmer, D.W. and Lemeshow, S. (2000) Applied Logistic Regression. Wiley, New York. https://doi.org/10.1002/0471722146

[35] Langley, J.A., Heady, E.O. and Olson, K.D. (1982) The Macro Implications of a Complete Transformation of U.S. Agricultural Production to Organic Farming Practices. Fourth International Conference on Resource Conserving, Environmental Sound Agricultural Alternatives, Cambridge, 18-20 August 1982.

[36] Crawford, C., Grossman, J., Warren, S.T. and Cubbage, F. (2015) Grower Communication Networks: Information Sources for Organic Farmers. Journal of Extension, 53, 1-4.

[37] Patrick, G., Ortmann, G.F., Musser, W.G. and Doster, H. (1993) Information Sources of Large-Scale Farmers. Choices 3 rd Quarter, 40-41. http://ageconsearch.umn.edu/bitstream/131148/2/LargeScaleFarmers.pdf

[38] Green, C. and Kremen, A. (2003) Organic Farming in 2000-2001: Adoption of Certified Systems. USDA ERS: Agricultural Information Bulletin \# 780. 
https://www.ers.usda.gov/publications/pub-details/?pubid=42492

[39] Kuminoff, N. and Wossink, A. (2005) Valuing the Option to Convert from Conventional to Organic Farming. AAEA Annual Meeting, Providence, July 2005.

[40] Barry, P.J., Baker, C.B., Ellinger, P.N. and Hopkin, J.A. (2000) Financial Management in Agriculture. Interstate Publishers, Inc., Danville.

[41] Dimara, E. and Skuras, D. (2003) Adoption of Agricultural Innovations as a TwoStage Partial Observability Process. Agricultural Economics, 28, 187-196. https://doi.org/10.1016/S0169-5150(03)00003-3

[42] D'souza, G., Cyphers, D. and Phipps, T. (1993) Factors Affecting the Adoption of Sustainable Agricultural Practices. Agricultural and Resource Economics Review, 22, 159-165. https://doi.org/10.1017/S1068280500004743

[43] Sattler, C. and Nagel, U.J. (2010) Factors Affecting Farmers Acceptance of Conservation Measures: A Case Study from North-Eastern Germany. Land Use Policy, 27, 70-77. https://doi.org/10.1016/j.landusepol.2008.02.002

[44] Phimister, E. and Roberts, D. (2006) The Effects of Off-Farm Work on the Intensity of Agricultural Production. Environmental and Resource Economics, 34, 493-515. https://doi.org/10.1007/s10640-006-0012-1 